\begin{tabular}{|c|c|c|}
\hline & INTERNATIONAL RE & JRNAL OF PHAI \\
\hline 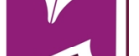 & www.irjponline.com & ISSN $2230-8407$ \\
\hline
\end{tabular}

\title{
ANTIDIABETIC ACTIVITY OF JATROPHA GOSSYPIFOLIA LINN ROOT EXTRACTS IN ALLOXAN INDUCED DIABETIC MICE
}

\author{
Harneet Singh and Surendra Kr. Sharma* \\ Department of Pharmaceutical Sciences, Guru Jambheshwar University of Science \& Technology, Hisar, Haryana, India \\ *Corresponding Author Email: harneetdilawary@yahoo.co.in
}

Article Received on: 20/03/13 Revised on: 01/04/13 Approved for publication: 17/05/13

DOI: $10.7897 / 2230-8407.04543$

IRJP is an official publication of Moksha Publishing House. Website: www.mokshaph.com

(C) All rights reserved.

\begin{abstract}
Diabetes is most common endocrine disease which exists globally and interests about $6 \%$ of the world population. The recommendation of W.H.O. about diabetes has led to a rise in investigation of medicinal plants for hypoglycemic agents. Decoction prepared from roots of Jatropha gossypifolia Linn is used in the treatment of diabetes and its associated complications. The aim of this study was to evaluate the hypoglycemic effect of successive extracts of the roots of the plant in comparison to metformin. Petroleum ether $\left(60-80^{\circ} \mathrm{C}\right)$, chloroform, methanol and aqueous extracts $(250 \mathrm{and} 500 \mathrm{mg} / \mathrm{kg}$ body weight) were orally administered to alloxan-induced diabetic mice for 7 days. Change in body weight and plasma glucose levels were estimated after the treatment. Methanol extract exhibited significant reduction in plasma glucose level as compared to diabetic control, followed by aqueous extract. Chloroform and petroleum ether extracts were comparatively less active. The results confirm the folklore use of the plant in management of diabetes.

Keywords: Jatropha gossypifolia, antidiabetic, blood glucose, alloxan.
\end{abstract}

\section{INTRODUCTION}

Diabetes mellitus is the most important disease involving the endocrine pancreas. The word 'diabetes' is derived from the Greek word 'diabainein' which means 'to pass through' and the word 'mellitus' means 'honey sweet'. It is characterized by an excess of sugar in the blood and urine, hunger, thirst and gradual loss of weight ${ }^{1}$. Diabetes mellitus is a medical disorder characterized by varying or persistent hyperglycemia with or without glycosuria ${ }^{2}$. Diabetes is one of the leading factor in causing heart disease, stroke, kidney damage as well as nerve complications, pregnancy complications and birth defects in children born to diabetic mothers ${ }^{3}$. The number of people suffering from diabetes worldwide is increasing at an alarming rate with a projected 366 million people likely to be affected by the year 2030 as against 191 million estimated in the year $2000^{4}$. India leads the world with largest number of diabetic subjects earning the dubious distinction of being termed the "diabetes capital of the world" with 41 million Indians having diabetes. Every fifth diabetic in the world is an Indian ${ }^{5}$. The World Health Organization Expert Committee on diabetes has recommended that traditional medicinal herbs be further investigated for hypoglycemic agents ${ }^{6}$. There are numerous plants which have the ability to reduce the glucose production, stimulate the utilization of glucose and combat with secondary complications. Out of an estimated 250,000 plants, less than $1 \%$ have been pharmacologically evaluated and only a fraction of these for diabetes. The most commonly used drugs of contemporary medicine such as aspirin, anti-malarials, anticancer, digitalis etc. originated from plant sources. Therefore, it is practical to look for options in herbal medicine for diabetes. On the basis of this report which lists the impending effectiveness of medicinal plant against diabetes, it can be believed that phytochemicals can play a vital role in the management of diabetes. This needs additional exploration before drugs and nutraceuticals can be developed from the natural resources. Most of the herbal therapies have not yet undergone proper scientific assessment and some have the ability to cause severe toxic effects and drug-to-drug interactions. Continual research is essential to elucidate the pharmacological activities of herbal remedies ${ }^{7}$.

Jatropha gossypifolia Linn is an erect, branched shrub, about 1.8 meters high, native of Brazil but now widespread throughout the tropical world. It has naturalized in many parts of India and listed as a weed. The plant is traditionally used in leprosy, diarrhea, dysentery, anemia, vertigo, malaria, toothache, as antidote for snake bite, antibiotic, insecticidal, blood purifier, purgative, stimulant, stomachic, febrifuge, emetic, emmenagogue, to treat wound, sores, boils, carbuncles, eczema, itches, ulcers, to reduce pain and to stop bleeding from skin and nose ${ }^{8}$. Decoction prepared from roots of Jatropha gossypifolia Linn is used in the treatment of diabetes ${ }^{9}$. Various parts of the plant have been shown to possess anti-cancer, antihypertensive, anti-malarial, antimicrobial, anti-oxidant, antitubercular, anti-viral, haemostatic and molluscicidal activity ${ }^{10}$. The present study intended to evaluate the hypoglycemic potential of the roots of Jatropha gossypifolia L. in alloxan induced diabetic mice.

\section{MATERIAL AND METHODS}

Collection and authentication

The plant material (roots) was collected from healthy plants of Jatropha gossypifolia L. from campus of Guru Jambheshwar University of Science \& Technology, Hisar, Haryana, in the month of October, 2011. Herbarium so prepared was authenticated by Dr. H. B. Singh (Scientist F and Head, Raw Materials Herbarium and Museum, NISCAIR, New Delhi) under voucher specimen no. NISCAIR/RHMD/Consult/-2011-12/1887/187 dated 16-112011 and a specimen was deposited in the department. The plant material was dried under shade and then coarsely powdered.

\section{Preparation of extracts}

Successive extracts of Jatropha gossypifolia L. root powder were prepared using soxhlet apparatus petroleum ether (60$80^{\circ} \mathrm{C}$ ), chloroform and methanol. Aqueous extract was than prepared by boiling the powder with water. 


\section{Animals used}

Swiss Albino mice (25-30 g) of either sex were procured from Lala Lajpat Rai University of Veterinary and Animal Sciences, Hisar, Haryana. The animals were housed under standard environmental condition of temperature $\left(25 \pm 2^{\circ} \mathrm{C}\right)$ and a 12 hour light-dark cycles with standard pellet diet and water ad libitum. All the experimental procedures and protocols were approved by the Institutional Animals Ethics Committee (Endst. no. IAEC/106-115, dated 23-05-12) as per CPCSEA guidelines. The animals were acclimatized for one week before use for experimentation.

\section{Hypoglycemic activity}

A freshly prepared solution of alloxan monohydrate $(150 \mathrm{mg} / \mathrm{kg}$ body weight) in normal saline was injected intraperitoneally to overnight fasted $\operatorname{rats}^{11}$. After 3 days, blood samples were collected retro-orbitally from inner canthus of eyes using Micro Hematocrit Capillaries, after at least 12 hours of fasted animals. Blood was kept in fluoride tubes. It was then centrifuged at $6000 \mathrm{rpm}$ for 15 minutes to obtain plasma. Glucose levels were estimated using Glucose Oxidase method and body weight was checked regularly up to stable hyperglycemia, after 1 week of alloxan injection. The animals having marked hyperglycemia (Fasting blood glucose 200 to $400 \mathrm{mg} / \mathrm{dl}$ ) were selected for the study. The animals were divided into eleven groups of six each, as follows:

Group 1: Normal control (treated with vehicle, $2 \% \mathrm{v} / \mathrm{v}$ Tween 80)
Group 2: Diabetic control (treated with vehicle, 2\% v/v Tween 80)

Group 3: Standard (treated with metformin, $50 \mathrm{mg} / \mathrm{kg}$ )

Group 4: Treated with $250 \mathrm{mg} / \mathrm{kg}$ body weight petroleum ether extract

Group 5: Treated with $500 \mathrm{mg} / \mathrm{kg}$ body weight petroleum ether extract

Group 6: Treated with $250 \mathrm{mg} / \mathrm{kg}$ body weight chloroform extract

Group 7: Treated with $500 \mathrm{mg} / \mathrm{kg}$ body weight chloroform extract

Group 8: Treated with $250 \mathrm{mg} / \mathrm{kg}$ body weight methanol extract

Group 9: Treated with $500 \mathrm{mg} / \mathrm{kg}$ body weight methanol extract

Group 10: Treated with $250 \mathrm{mg} / \mathrm{kg}$ body weight aqueous extract

Group 11: Treated with $500 \mathrm{mg} / \mathrm{kg}$ body weight aqueous extract

The animals received the treatment for 7 days. Fasting plasma glucose levels were estimated on day 0 and 7 . Blood was withdrawn by retro-orbital puncture and plasma glucose levels were estimated by Glucose Oxidase Peroxidase $\operatorname{method}^{12-13}$.

\section{Statistical analysis}

Statistical analysis was performed using one-way ANOVA followed by Dunnett's $t$-test. Data were considered significant at $\mathrm{P}<0.01$. All the results are expressed as mean \pm standard error of mean (SEM).

Table 1: Effect of Jatropha gossypifolia L. root extracts on plasma glucose levels and body weight in diabetic mice

\begin{tabular}{|c|c|c|c|c|}
\hline \multirow{2}{*}{ Group } & \multicolumn{2}{|c|}{ Plasma glucose levels (mg/dl) } & \multicolumn{2}{c|}{ Body weight (g) } \\
\cline { 2 - 5 } & Day 0 & Day 7 & Day 0 & Day 7 \\
\hline Normal control & $89.66 \pm 2.406^{* *}$ & $91.3 \pm 2.667^{* *}$ & $28.8 \pm 0.8$ & $30.1 \pm 0.5$ \\
\hline Diabetic control & $282.83 \pm 3.493$ & $298.67 \pm 2.654$ & $28.4 \pm 0.9$ & $26.6 \pm 0.7^{\mathrm{b}}$ \\
\hline Standard (Metformin, $50 \mathrm{mg} / \mathrm{kg})$ & $271.83 \pm 4.447$ & $122.33 \pm 1.585^{* *}$ & $27.8 \pm 0.7$ & $28.6 \pm 0.4$ \\
\hline Petroleum ether extract $(250 \mathrm{mg} / \mathrm{kg})$ & $287.45 \pm 5.221$ & $259.67 \pm 3.281^{* *}$ & $26.2 \pm 0.5^{\mathrm{b}}$ & $25.3 \pm 0.6^{\mathrm{b}}$ \\
\hline Petroleum ether extract $(500 \mathrm{mg} / \mathrm{kg})$ & $275.62 \pm 4.383$ & $243.47 \pm 4.334^{* *}$ & $27.9 \pm 0.3$ & $27.0 \pm 0.4^{\mathrm{b}}$ \\
\hline Chloroform extract $(250 \mathrm{mg} / \mathrm{kg})$ & $271.49 \pm 3.593$ & $248.52 \pm 2.478^{* *}$ & $25.5 \pm 0.8^{\mathrm{b}}$ & $24.1 \pm 0.6$ \\
\hline Chloroform extract $(500 \mathrm{mg} / \mathrm{kg})$ & $269.83 \pm 4.220$ & $228.43 \pm 5.011^{* *}$ & $28.4 \pm 0.4$ & $27.2 \pm 0.3^{\mathrm{a}}$ \\
\hline Methanol extract $(250 \mathrm{mg} / \mathrm{kg})$ & $281.23 \pm 3.881$ & $159.33 \pm 4.832^{* *}$ & $29.3 \pm 0.5$ & $29.6 \pm 0.3$ \\
\hline Methanol extract $(500 \mathrm{mg} / \mathrm{kg})$ & $276.83 \pm 5.110$ & $147.17 \pm 3.162^{* *}$ & $26.8 \pm 0.7^{\mathrm{b}}$ & $27.2 \pm 0.6^{\mathrm{a}}$ \\
\hline Aqueuos extract $(250 \mathrm{mg} / \mathrm{kg})$ & $279.47 \pm 4.720$ & $180.5 \pm 4.032^{* *}$ & $27.4 \pm 0.9^{\mathrm{a}}$ & $27.3 \pm 0.8^{\mathrm{a}}$ \\
\hline Aqueuos extract $(500 \mathrm{mg} / \mathrm{kg})$ & $284.45 \pm 4.560$ & $161.67 \pm 3.691^{* *}$ & $28.3 \pm 0.4$ & $28.4 \pm 0.5$ \\
\hline \multicolumn{2}{|c|}{ Data expressed as $\mathrm{mean} \pm$ S.E.M., $\mathrm{n}=6,{ }^{*} \mathrm{p}<0.05, * * \mathrm{p}<0.01$, vs diabetic control, Dunnet's test; } \\
\hline
\end{tabular}

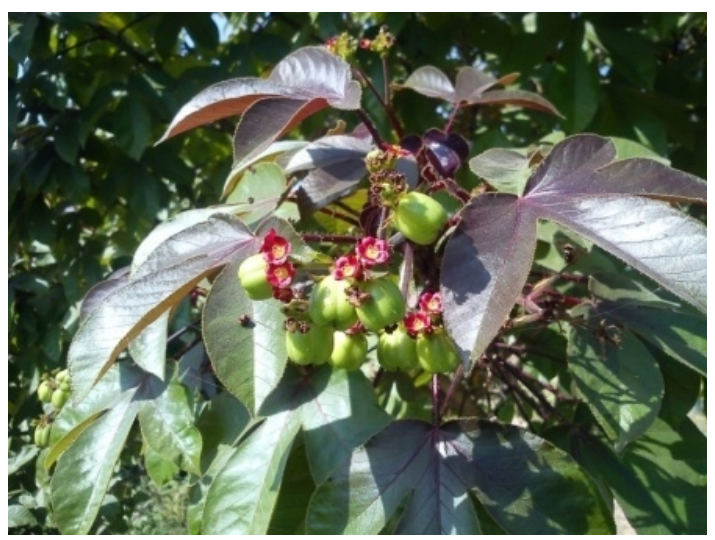

Twig of Jatropha gossypifolia Linn. (Euphorbiaceae)

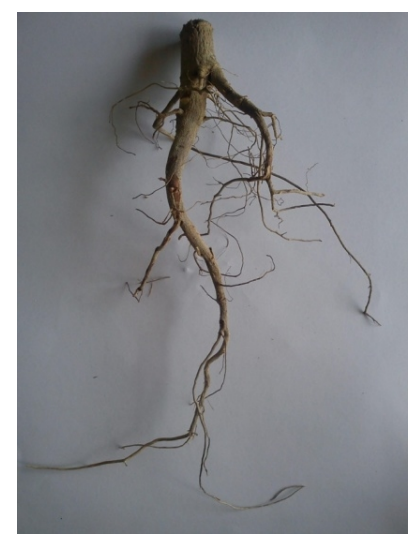

Roots of Jatropha gossypifolia Linn. (Euphorbiaceae) 


\section{RESULTS}

Methanol extract exhibited significant reduction in plasma glucose as compared to diabetic control animals and the body weight of the animals showed a rise resulting from the treatment as shown in Table 1. Aqueous extract was less active in reducing the plasma glucose levels. Chloroform and petroleum ether extracts were however inactive.

\section{DISCUSSION}

Non-insulin dependent diabetes mellitus (NIDDM) state, which is widespread amongst diabetic subjects, is characterized by reduced concentration of circulating insulin, poor insulin sensitivity or insulin resistant and poor glucose tolerance resulting in high sugar in plasma. Hyperglycemia condition by itself impairs insulin secretion ${ }^{14}$. The results clearly demonstrate that the extracts of Jatropha gossypifolia L. roots exert significant anti-hyperglycemic effects in alloxan-induced diabetic mice. In alloxan-induced diabetic mice, where $\beta$-cells are moderately compromised, higher dose of methanolic extract $(500 \mathrm{mg} / \mathrm{kg}$ b.w.) was more potent. The more pronounced effect of the extract in alloxaninduced diabetic mice may possibly be due to the partial or compromised effect of insulin in diabetic condition and conversely a greater and more direct role of the hypoglycemic principle present in the extract. Several hypoglycemic principles have been reported which effect hypoglycemia ${ }^{15-17}$. Further studies may be undertaken in order to elucidate the probable mechanism of action and to isolate bioactive phytoconstituents from the plant.

\section{ACKNOWLEDGEMENT}

The authors are thankful Institutional Animal Ethics Committee, G.J.U.S \&T., Hisar for kind approval of animal study.

\section{REFERENCES}

1. Khan MTH. Diabetes mellitus treatment and complications. Hamdard Medicus. 2000; 43(1-4): 77-83.

2. Akhtar J, Jamil S, Azhar MU. Diabetes mellitus prevention and management. Natural Product Radiance. 2005; 4(5): 413-415.

3. Memon BA, Bhatti K. Diabetes mellitus a chronic metabolic disorder. Hamdard Medicus. 2002; 45(1-4): 57-67.

4. Wild SG, Roglic A, Green R, King H. Global prevalence of diabetesEstimated for the year 2000 and projection for 2030. Diabetes Care. 2004 27:1047-1054. http://dx.doi.org/10.2337/diacare.27.5.1047 PMid: 15111519
5. Joshi SR, Parikh RM. India - Diabetes capital of the world: Now heading towards hypertension. Journal of the Association of Physicians of India. 2007; 55: 323-324. PMid: 17844690

6. Day C. Traditional plant treatments for diabetes mellitus: Pharmaceutical foods. Br J Nutr .1998; 80: 5-6. http://dx.doi.org/10.1017/S000 7114598001718 PMid: 9797638

7. Prabhakar PK, Doble M. Mechanism of action of natural products used in the treatment of diabetes mellitus. Chinese Journal of Integrative Medicine. 2011; 17(8): 563-574. http://dx.doi.org/10.1007/s11655-011-0810-3 PMid: 21826590

8. Kirtikar KR, Basu BD. Indian Medicinal Plants. Allahabad: International Book Distributors; 1996. PMid: 9985545

9. Koffi N, Edouard KN, Kouassi K. Ethnobotanical study of plants used to treat diabetes, in traditional medicine, by Abbey and Krobou people of Agboville (Côte-d'Ivoire). American Journal of Scientific Research. 2009; 4: $45-58$.

10. Sharma SK, Singh H. A review on pharmacological significance of genus Jatropha (Euphorbiaceae). Chinese Journal of Integrative Medicine 2012; 18(11): 868-880. http://dx.doi.org/10.1007/s11655-012-1267-8 PMid: 23086490

11.Matteucci E, Giampietro O. Proposal open for discussion: defining agreed diagnostic procedures in experimental diabetes research. Journal of Ethnopharmacology. 2008; 115(2): 163-172. http://dx.doi.org/10.1016 /j.jep.2007.08.040 PMid: 17961942

12. Bhatia A, Mishra T. Hypoglycemic activity of Ziziphus mauritiana aqueous ethanol seed extract in alloxan-induced diabetic mice. Pharmaceutical Biology. 2010; 48(6): 604-610. http://dx.doi.org/10.3109/ 13880200903218935 PMid: 20645731

13. Kumar S, Kumar D, Deshmukh RR, Lokhande PD, More SN, Rangari VD. Antidiabetic potential of Phyllanthus reticulatus in alloxan-induced diabetic mice. Fitoterapia. 2008; 79(1): 21-23. http://dx.doi.org/ 10.1016/j.fitote.2007.06.012 PMid: 17855019

14. Davis SN, Granner DK. Insulin, oral hypoglycemic agents and the pharmacology of the endocrine pancreas. In: Goodman, LS, Gilman AG, editors. The Pharmacological Basis of Therapeutics, $9^{\text {th }}$ ed. New York: Mcgraw Hill; 1996. p. 1487-1511

15. Hikino $\mathrm{H}$, Takakazu $\mathrm{M}$, Yoshiteru $\mathrm{O}$, Konno $\mathrm{C}$. Isolation and hypoglycemic activity of Moran A, a glycoprotein of Morus alba root bark. Planta Medica.1985; 51: 159-160. http://dx.doi.org/10.1055/s-2007-969435 PMid: 4034734

16. Akhtar MS, Ali MR. Study of hypoglycemic activity of Cuminum nigrum seeds in normal and alloxan diabetic rabbits. Planta Medica.1985; 51: 81-85. http://dx.doi.org/10.1055/s-2007-969411 PMid: 4034738

17. Takahasi M, Konno C, Hikino H. Isolation and hypoglycemic activity of Anemorans A, B, C and D, glycans of Anemarrhema asphodelcides rhizomes. Planta Medica.1985; 51: 100-102. http://dx.doi.org/10.1055/s2007-969417 PMid: 4034726

\section{Cite this article as:}

Harneet Singh and Surendra Kr. Sharma. Antidiabetic activity of Jatropha gossypifolia Linn root extracts in Alloxan induced diabetic mice. Int. Res. J. Pharm. 2013; 4(5):210-212 